\title{
Protein phosphorylation in the organ of Corti: Differential regulation by second messengers between base and apex
}

\author{
Donald E. Coling and Jochen Schacht \\ Kresge Hearing Research Institute, University of Michigan, Ann Arbor, Michigan, U.S.A.
}

(Received 23 May 1991; accepted 20 July 1991)

\begin{abstract}
Major aspects of cellular physiology are regulated by the phosphorylation state of proteins through the action of protein kinases and protein phosphatases. Phosphorylation of proteins by endogenous protein kinase activity was assayed in homogenates from guinea pig inner ear tissues with $\left[\gamma_{-}{ }^{32} \mathrm{P}\right]$ ATP. Phosphoproteins showed distinct distributions in organ of Corti, lateral wall and spiral ganglion. In the organ of Corti, several protein kinase activities were distinguished by their activation by appropriate agonists: protein kinase $\mathrm{C}$, calmodulin-dependent protein kinases and cyclic nucleotide-dependent protein kinases. Twelve putative substrates for these kinases were identified in organ of Corti on the basis of increased ${ }^{32} \mathrm{P}$-incorporation with addition of lipids, calmodulin, and cyclic nucleotides, respectively. In addition, differences in phosphorylation were observed between the base and apex of the organ of Corti. ${ }^{32} \mathrm{P}$-incorporation into proteins of molecular weights between 45 and $100 \mathrm{kDa}$ was significantly higher in apical tissuc than in tissue from the base. In contrast, phosphate incorporation into proteins of around $29 \mathrm{kDa}$ was much lower in apical tissues than in basal tissues. Furthermore, labeling of both the high and low molecular weight proteins from the apex but not the base markedly increased in response to calcium. These data indicate the presence of differential modes of regulation that may underlie structural and functional gradients along the sensory epithelium.
\end{abstract}

Inner ear; Organ of Curti; Protein kinases; Protein phosphatases; Phosphorylation; Second messengers; Calınodulin; AMP, cyclic; GMP, cyclic; Calcium; Lipids

\section{Introduction}

A wide variety of extracellular and intracellular signals induce changes in cellular physiology by regulating the phosphorylation state of proteins through the action of protein kinases and protein phosphatases. Many cellular responses that involve calcium are regulated by protein phosphorylation, including glucose metabolism (Sutherland, 1972), cell motility (Adelstein and Eisenberg, 1980), ion channel conductance (Levitan, 1988) and neurotransmitter release (Nestler and Greengard, 1984). Calcium may act on these protein phosphorylation systems either directly by allosteric activation of enzymes or indirectly through. calcium-binding regulatory proteins like calmodulin (Campbell, 1983; Cohen and Klee, 1988). In addition, cyclic nucleotides (cyclic AMP and cyclic GMP) and lipids (such as diacylglycerol) regulate other distinct classes of protein kinases (Nairn et al., 1985).

Several observations lead to the hypothesis that calcium-dependent protein phosphorylation plays important roles in inner ear function. The abundance of

Correspondence to: Jochen Schacht, Kresge Hearing Research Institute, University of Michigan, 1301 East Ann Street, Ann Arbor, MI 48109-0506, U.S.A. Fax: (313) 764-0014. actin within stereocilia and cuticular plate of hair cells suggests the presence of actomyosin or actomyosin-like motility systems (Flock, 1980; Flock et al., 1981). In such motile systems, the initiation and rates of the energy releasing reaction, ATP hydrolysis, are regulated through protein phosphorylation and dephosphorylation by a system of enzymes which includes the calcium/calmodulin-dependent myosin light chain kinase, a cyclic AMP-dependent kinase and at least one protein phosphatase (Cohen and Klee, 1988; Cohen, 1989). Calmodulin has been localized in hair cells (Slepecky, 1985; Shepherd et al., 1989) and a myosin light chain kinase activity has been identified in whole organ of Corti preparations (Sriklai et al., 1986). Calmodulin antagonists block adaptation in bull frog vestibular hair cells (Corey et al. 1987) and calcium-dependent 'slow motility' in guinea pig outer hair cells (Dulon et al., 1990). These data suggest a role for calcium/calmodulin-dependent protein phosphorylation in these processes.

Another suggestive link of cochlear function to protein phosphorylation is the presence of a muscarinic acetylcholine receptor coupled to phosphatidylinositol $(4,5)$-bisphosphate (PtdIns $\mathrm{P}_{2}$ ) hydrolysis recently characterized in mammalian cochlea (Guiramand ct al., 1990) and localized to the organ of Corti (Niedzielski and Schacht, 1991). Although the effects of PtdInsP $P_{2}$ 
hydrolysis have not been investigated in the inner ear, in other well characterized systems the products of this phospholipase C-mcdiated hydrolysis, diacylglyecrol and inositol 1,4,5-trisphosphate activate protein kinase C (Nishizuka, 1989) and mobilize intracellular calcium stores (Berridge, 1989), respectively. Thus, it is possible that protein kinase $\mathrm{C}$ and calcium/calmodulin-dependent protein kinases in the organ of Corti may be activated by the efferent neurotransmitter.

To date, no experiments have been reported on the regulation of cochlear protein phosphorylation. We have previously studied regulatory mechanisms of the inner ear which involve participation of both lipids and proteins with particular emphasis on the role of phospholipid hydrolysis in initiating calcium-mediated signaling pathways ( nnniko et al., 1981; Anniko and Schacht, 1981; Kilian and Schacht, 1977, 1979; Schacht 1982, 1985; Schacht and Zenner 1987; Wang and Schacht, 1990). We have now extended these investigations to studies of protein phosphorylation and its control by second messenger systems including calcium, calmodulin, lipids and cyclic nucleotides. In this first communication, we identify putative substrates of protein kinases belonging to the families of protein kinases $\mathrm{C}$, calmodulin-dependent protein kinases and cyclic nucleotide-dependent protein kinases. Additionally, we provide evidence for differential regulation of calcium-dependent protein phosphorylation between the base and apex of the organ of Corti. Parts of this work have been presented in preliminary form (Coling and Schacht, 1989, 1990).

\section{Methods}

lissues from pigmented guinea pigs $(250-400 \mathrm{~g})$ were dissected in Hanks' Balanced Salt Solution (Gibco, Gaithersburg, MD) with $10 \mathrm{mM}$ sodium N-2Hydroxyethylpiperazine- $N^{\prime}$-2-ethanesulfonic acid (HEPES), pH 7.4. Osmolarity was adjusted to $300 \pm 1$ mOsm with $\mathrm{NaCl}$. Prior to use, the solution was gassed with $95 \% \mathrm{O}_{2}, 5 \% \mathrm{CO}_{2}$ for $30 \mathrm{~min}$ and the $\mathrm{pH}$ was readjusted to 7.4 .

After removing the bony capsule of the cochlea, inner ear tissue was divided into three components: 'lateral wall tissue,' consisting of spiral ligament and stria vascularis; 'organ of Corti,' including tectorial and basilar membranes, hair cells and supporting cells and bounded by Claudius' cells on the outer periphery, and spiral limbus cells on the inner periphery; and 'spiral ganglion,' consisting of the modiolus, ganglion cell bodies and the nerve fiber core. Although care was taken to harvest 'organ of Corti' tissue completely, in some cases, loss of Hensen's cells and some outer hair cells in the hook region and the first one third turn from the base could not be avoided.
After dissection, the tissue was washed and sonicated in homogenization buffer $(10 \mathrm{mM}$ sodium HEPES, pH 7.4, $10 \mathrm{mM} \mathrm{MgCl}_{2}, 0.2 \mathrm{mM}$ ethyleneglycol-bis-( $\beta$-aminoethyl ether) $N, N, N^{\prime}, N^{\prime}$-tetra-acetic acid (EGTA) with $200 \mu \mathrm{M}$ phenylmethylsulfonylfluoride, $2 \mu \mathrm{M}$ pepstatin $\mathrm{A}$, and $2 \mu \mathrm{M}$ leupeptin as protease inhibitors [Sigma, St. Louis, MO]). Proteins were labeled in an endogenous kinase assay with 10 to $20 \mu \mathrm{g}$ total protein in homogenization buffer and additions of calcium, calmodulin (from bovine brain, Sigma), cyclic nucleotides or lipids as indicated in the figure legends. Labeling was initiated by adding $7.5 \mu \mathrm{M}\left[\gamma_{-}{ }^{32} \mathrm{P}\right] \mathrm{ATP}$ (Amersham, Arlington Heights, IL; spec. activity 1.06 $\mathrm{CBq} / \mathrm{mol})$. Reactions were allowed to proceed for 1.5 to $15 \mathrm{~min}$ at $37^{\circ} \mathrm{C}$ and then stopped by addition of $62.5 \mathrm{mM}$ Tris- $\mathrm{HCl}, \mathrm{pH} 6.8,2 \%$ sodium dodecyl sulfate, $10 \%$ glycerol, $5 \%$ 2-mercaptoethanol, $0.003 \%$ bromophenol blue (final concentrations) and boiling for 3 $\min$.

Proteins were separated by sodium dodecyl sulfate polyacrylamide gel electrophoresis (SDS-PAGE) on 3 to $20 \%$ acrylamide gradient gels (Laemmli, 1970). Molecular weight was estimated from protein standards by second order polynomial regression. Phosphoproteins were visualized by autoradiography and incorporation of ${ }^{32} \mathrm{P}$ was determined by liquid scintillation counting of bands cut from dried gels. Changes in ${ }^{32} \mathrm{P}$-incorporation resulting from the addition of kinase activators are compared to controls (no addition) run in the same assays and reported as the mean $(N=5-7)$ percent of control + standard error. Only those proteins showing a statistically significant change $(P<0.05$, paired $t$-test $)$ are considered putative substrates for specific protein kinases with the exception of a $50 \mathrm{kDa}$ triplet (see Results).

\section{Results}

Rates of protein phosphorylation in response to calcium and calmodulin are relatively high in the organ of Corti

Preliminary time course experiments in organ of Corti indicated that a 15 min incubation period provided sufficient time for clearly detectable labeling of 15 to 20 phosphoproteins in a typical experiment. Phosphate incorporation in most of these proteins was still increasing after $15 \mathrm{~min}$. Thus, addition of an agent that stimulates their kinases resulted in increased incorporation of ${ }^{32} \mathrm{P}$ (Fig. 1, bottom, compare lanes 'to ' + ' for assays \pm calcium). As an exception, phosphorylation of three proteins in the region of 23 to $29 \mathrm{kDa}$ reached a plateau within $1 \mathrm{~min}$ in the absence of kinase activators.

Next, we compared rates of protein phosphorylation of cochlear and other tissues and surveyed the presence of calcium-dependent kinases. Homogenates from 

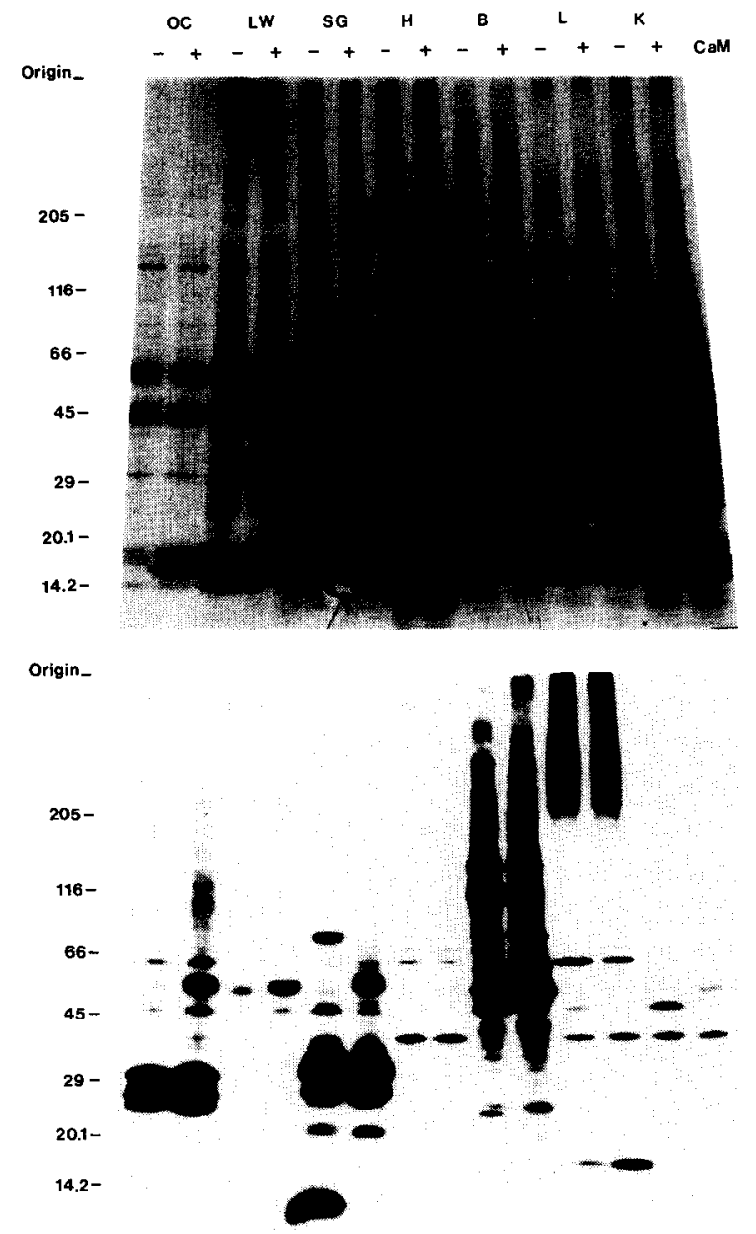

Fig. 1. Protein staining and protein phosphorylation in the organ of Corti. Homogenates from seven tissues, organ of Corti (OC), lateral wall (LW), spiral ganglion (SG), heart (H), temporal cortex of brain (B), liver (L) and kidney (K) were labeled for 15 min with $\left[\gamma^{-32} \mathrm{P}\right]$ ATP as described in Methods in the presence of combined $0.6 \mathrm{mM} \mathrm{CaCl}$ and $10 \mu \mathrm{M}$ CaM $(+)$ or neither ( - ). Proteins were separated by SDS-PAGE. Numbers to the left represent molecular weights of protein standards. top: Gel stained for protein with Coomassie Blue. bottom: Corresponding autoradiograph of ${ }^{32} \mathrm{P}$-phosphoproteins.

organ of Corti, lateral wall, spiral ganglion, heart, brain, liver and kidney were labeled with $\left[\gamma^{32}\right.$ P]ATP in the absence or presence of exogenous calcium and calmodulin. Protein concentrations were adjusted to $0.3 \mathrm{mg} / \mathrm{ml}$ for organ of Corti, $0.4 \mathrm{mg} / \mathrm{ml}$ for lateral wall, and $1 \mathrm{mg} / \mathrm{ml}$ for spiral ganglion and other tissues. These differences in concentration are reflected in protein staining after separation by electrophoresis (Fig. 1, top). Most of the tissues exhibited a characteristic pattern of protein expression. However, it was difficult to distinguish between the protein staining patterns for organ of Corti and lateral wall at the level of one dimensional SDS-PAGE (Fig. 1, top, lanes OC compared to $\mathbf{L W}$ ). Added calmodulin was detectable in lanes indicated ' + ' as a multimer between 15 and 17 $\mathrm{kDa}$ (Fig. 1, top) indicative of the presence of calcium in the assays (Burgess 1980).
Total isotope incorporation (Fig. 1, bottom) in organ of Corti proteins, particularly in the presence of calcium and calmodulin, (' + ' lanes) was higher than in lateral wall tissue, heart or kidney and comparable to liver and neural tissues (spiral ganglion and temporal cortex). The patterns of ${ }^{32} \mathrm{P}$-incorporation into individual phosphoproteins also exhibit marked differences between the tissues tested. Most notable were the distinct patterns of ${ }^{32} \mathrm{P}$-incorporation in organ of Corti and lateral wall in the face of the similar protein staining of these two tissues. The phosphorylation pattern responded to the addition of calcium and calmodulin in all tissues, with major changes apparent in the organ of Corti and spiral ganglion.

In the spiral ganglion, phosphorylation of a $12 \mathrm{kDa}$ protein was very prominent in low calcium. Although several tissues tested contained proteins of this mobility (Fig. 1, top), in no case was ${ }^{32} \mathrm{P}$-incorporation comparable to that of the spiral ganglion (Fig. 1, bottom). The amount of ${ }^{32} \mathrm{P}$-incorporation in an $81 \mathrm{kDa}$ protein was also much greater than in corresponding proteins from other tissues except brain (Fig. 1, bottom). Labeling of both the $12 \mathrm{kDa}$ and $81 \mathrm{kDa}$ proteins was significantly reduced in the presence of calcium and calmodulin. (Fig. 1, bottom, lane SG ' + '). Preliminary results suggest this type of regulation involves a calcium/calmodulin-dependent inhibition of the kinase(s) acting on these proteins (Naik, Coling and Schacht, manuscript in preparation).

Several proteins in organ of Corti homogenates are substrates for kinases regulated by specific second messenger systems

In order to find appropriate concentrations of activators for specific protein kinases, tissue homogenates from organ of Corti, lateral wall and spiral ganglion were labeled in the presence of varying concentrations of cyclic AMP, cyclic GMP, calmodulin or lipids (phosphatidylserine and 1,2-diolein, a diacylglycerol). Cyclic nucleotides were tested at $0.1,1$ or $10 \mu \mathrm{M} .{ }^{32} \mathrm{P}$-incorporation was generally highest at $1 \mu \mathrm{M}$ (data not shown), suggesting that $10 \mu \mathrm{M}$ levels of cyclic AMP or cyclic GMP may compete with ATP for the kinases. In the case of calmodulin stimulation, ${ }^{32} \mathrm{P}$-incorporation either showed a monotonic increase with increasing activator or leveled off between 1 and $10 \mu \mathrm{M}$ calmodulin. For stimulation of protein kinase $\mathrm{C}$ by lipids, 100 $\mu \mathrm{g} / \mathrm{ml}$ phosphatidylserine and $10 \mu \mathrm{g} / \mathrm{ml}$ 1,2-diolein were used (Thomas et al., 1987). Doubling the concentrations of each of the lipids produced no obvious increase in kinase stimulation. As a result of these preliminary trials, stimulation of kinases was assayed in the presence of either $1 \mu \mathrm{M}$ cyclic AMP or cyclic GMP, $10 \mu \mathrm{M}$ calmodulin or $100 \mu \mathrm{g} / \mathrm{ml}$ phosphatidylserine and $10 \mu \mathrm{g} / \mathrm{ml} \mathrm{1,2-diolein.} \mathrm{Calcium} \mathrm{for}$ 
TABLE I

ORGAN OF CORTI PHOSPHOPROTEINS: REGULATION BY SECOND MESSENGERS

\begin{tabular}{|c|c|c|c|}
\hline$\overline{\mathrm{MW}(\mathrm{kDa})^{1}}$ & Agonist $^{2}$ & $\%$ Stimulation $^{3}$ & Possible Identity ${ }^{4}$ \\
\hline $95.2 \pm 0.7$ & cAMP & $16.2 \pm 5.6$ & \\
\hline $44.5 \pm 0.2$ & cAMP & $26.6 \pm 13.2$ & ${ }^{*} \mathrm{CaM}$ kinase $\mathrm{I}^{5}$ \\
\hline $25.0 \pm 0.3$ & cAMP & $21.6 \pm 10.4$ & \\
\hline $23.4 \pm 0.3$ & cAMP & $23.9 \pm 10.6$ & OCP-II, ${ }^{6} \mathrm{G}$-substrate ${ }^{7}$ \\
\hline $14.5 \pm 0.2$ & cAMP & $18.8 \pm 8.5$ & \\
\hline $23.4 \pm 0.3$ & cGMP & $17.7 \pm 7.5$ & OCP-II, G ${ }^{*}$-substrate \\
\hline $04.9 \pm 0.4$ & lipids & $18.0 \pm 8.3$ & timbrin ${ }^{8}$ \\
\hline $23.4 \pm 0.3$ & lipids & $17.8 \pm 6.3$ & OCP-II, $\mathrm{G}^{*}$-substrate \\
\hline $20.4 \pm 0.2$ & lipids & $16.5 \pm 7.0$ & ${ }^{*}$ myosin light chain ${ }^{9}$ \\
\hline $19.4 \pm 0.3$ & lipids & $59.7 \pm 13.0$ & ${ }^{*}$ myosin light chain \\
\hline $11.6 \pm 0.2$ & lipids & $50.8 \pm 12.1$ & \\
\hline $100.6 \pm 0.7$ & $\mathrm{CaM}$ & $62.4 \pm 23.0$ & $\begin{array}{l}\text { dynamin, " } \\
{ }^{*} \text { elongation factor } 2 "\end{array}$ \\
\hline $64.9 \pm 0.4$ & CaM & $48.6 \pm 13.9$ & fimbrin \\
\hline 50 triplet & $\mathrm{CaM}$ & $>100$ & ${ }^{*}$ CaM kinase II \\
\hline $44.5 \pm 0.2$ & $\mathrm{CaM}$ & $44.6 \pm 14.6$ & ${ }^{*}$ CaM kinase I \\
\hline $35.8 \pm 0.3$ & $\mathrm{CaM}$ & $30.4 \pm 11.9$ & OCP-I \\
\hline
\end{tabular}

${ }^{1}$ Mean molecular weight $\pm\left(\right.$ SEM),$N=6$ to $12 .{ }^{2}$ Agonists: $1 \mu \mathrm{M}$ cyclic nucleotide, $10 \mu \mathrm{M}$ calmodulin $(\mathrm{CaM})$ or lipids $(100 \mu \mathrm{g} / \mathrm{ml}$ phosphatidylserine plus $10 \mu \mathrm{g} / \mathrm{ml}$ 1,2-diolein). Calcium for all reactions: $0.2 \mathrm{mM}$ FGTA, $0.6 \mathrm{mM} \mathrm{CaCl} 2 .{ }^{3}$ Means \pm SEM. of $N=7$ for cAMP and cGMP, $N=5$ for CaM and $N=6$ for lipid stimulation. Only those proteins whose phosphorylation was significantly elevated over control $(P \leqslant 0.05)$ are listed. ${ }^{4}$ Tentative identification based on electrophoretic properties and, in some cases $(*)$, in response to stimulation. ${ }^{5}$ Nairn et al., 1985 (review). ${ }^{6}$ Thalmann et al., 1980. ${ }^{7}$ Schlichter et al., 1978. ${ }^{8}$ Bretscher and Weber, 1980. ${ }^{4}$ Adelstein and Eisenberg, 1980 (review). ${ }^{10}$ Shptner and Vallee, 1989. "Ryazenov, 1987; Nairn and Palfrey, 1987.

each experimental condition and control was $0.6 \mathrm{mM}$ $\mathrm{CaCl}_{2}$ buffered with $0.2 \mathrm{mM}$ EGTA.

${ }^{32} \mathrm{P}$-incorporation increased in the presence of calmodulin for four well-separated proteins $(36,45,65$ and $100 \mathrm{kDa} ; P<0.05$, Table I) and for a triplet in the region of $50 \mathrm{kDa}$ (Fig. 2). Although the largest increase in ${ }^{32} \mathrm{P}$-incorporation was observed for the $50 \mathrm{kDa}$ triplet (1.5- to 3-fold over control), individual statistical analyses of data for members of the triplet will require resolution by an alternative separation method. Calmodulin-dependent stimulations were specific for the 36,50 and $100 \mathrm{kDa}$ proteins, i.e. their phosphorylation was not significantly affected by cyclic nucleotides or lipids. The $45 \mathrm{kDa}$ protein appeared to be a substrate for both calmodulin- and cyclic AMP-dependent activities while the $65 \mathrm{kDa}$ protein appeared to be an effective substrate for both a C-kinase and a calmodulin-dependent kinase activity (Fig. 3 and Table I).

Addition of lipids to tissue homogenates from organ of Corti revealed four potential C-kinase substrates. Bands at $12,19,20$ and $23 \mathrm{kDa}$ showed statistically significant increases in phosphorylation upon the addition of lipid (Table I). The increases in the 12, 19, and
$20 \mathrm{kDa}$ phosphoproteins were specific for lipid stimulation. The $23 \mathrm{kDa}$ protein may be a substrate for cyclic AMP- and cyclic GMP-dependent protein kinases in addition to protein kinase $\mathrm{C}$. It is possible that this multiple phosphorylation (and that of the 45 and 65 $\mathrm{kDa}$ proteins mentioned above) involves different phosphorylation sites on the same protein; on the other hand, different proteins could comigrate on this one-dimensional gel system.

Phosphorylation of three additional proteins from the organ of Corti $(15,24$ and $95 \mathrm{kDa})$ was significantly increased by addition of cAMP. These appear to be specific substrates for a cyclic AMP-dependent kinase since addition of the other agents did not induce any significant changes (Table I).

Regional assays of the organ of Corti reveal base to apex differences in calcium-dependent kinase activity

The organ of Corti was divided at a point two and a half turns from the apex resulting in nearly equal protein for basal and apical portions. Tissue homogenates were labeled with $\left[\gamma_{-}{ }^{32} \mathrm{P}\right] \mathrm{ATP}$ in either the absence or presence of calcium (Fig. 4). In the region of 45 to $100 \mathrm{kDa}$ several phosphoproteins were ob-
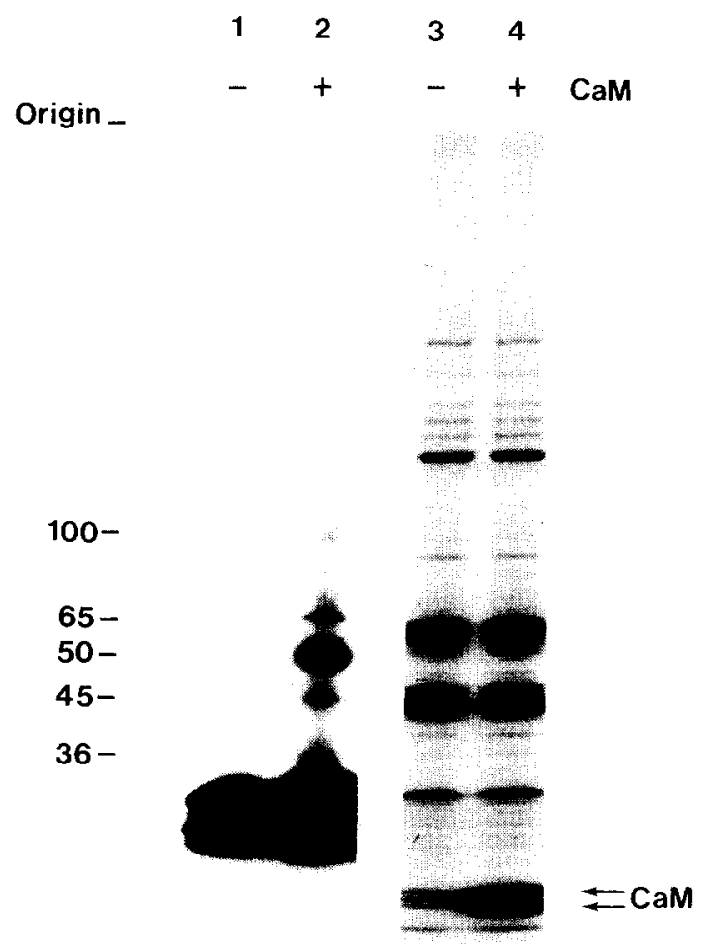

Fig. 2. Phosphorylation of five organ of Corti proteins is stimulated by calmodulin. Proteins were labeled with $\left[\gamma_{-}{ }^{32} \mathrm{P}\right] \mathrm{ATP}$ for $15 \mathrm{~min}$ with $0.6 \mathrm{mM} \mathrm{CaCl}_{2}$ in the absence or presence of $10 \mu \mathrm{M}$ calmodulin (CaM). Following protein staining (lanes $3 \& 4$ ), SDS gels were processed for autoradiography (lanes 1 \& 2). Molecular weight (kDa) is given for 5 proteins, including a $50 \mathrm{kDa}$ triplet, whose ${ }^{32} \mathrm{P}$-incorporation consistently increased with CaM ( $p<0.05)$. 
served in the apex but not appreciably in the base. In contrast, labeling of proteins in the low molecular weight region ( $29 \mathrm{kDa}$ and lower) appeared more pronounced in the base. Two phosphoproteins, not clearly identified in whole organ of Corti, were observed after separation of apical and basal tissues ( 27 and $47 \mathrm{kDa}$ ). While the $27 \mathrm{kDa}$ protein was also detectable in assays of whole organ of Corti, its resolution was impaired by the major 25 and $29 \mathrm{kDa}$ proteins. The $47 \mathrm{kDa}$ phosphoprotein was only detected by separate analysis of tissue from base and apex.

Some of the proteins previously identified as potential calmodulin-dependent kinase substrates in the whole organ of Corti (50 kDa region, 65 and $100 \mathrm{kDa}$ ) showed a calcium-dependent increase in ${ }^{32} \mathrm{P}$-incorpo-
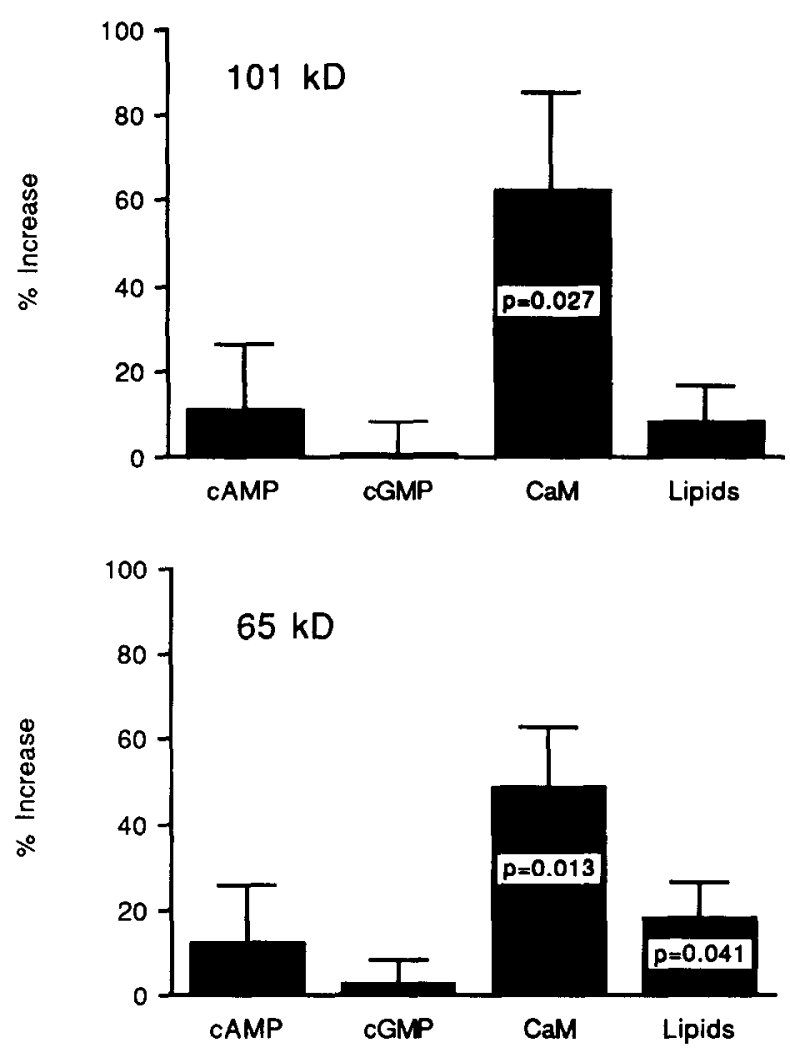

Fig. 3. Calmodulin-dependent phosphorylations of organ of Corti proteins are specific. $1 \mu \mathrm{M}$ cyclic AMP or cyclic GMP, $10 \mu \mathrm{M}$ CaM or lipids $(100 \mu \mathrm{g} / \mathrm{ml}$ phosphatidylserine plus $10 \mu \mathrm{g} / \mathrm{ml} 1,2$-diolein) were used to stimulate A-, G-, CaM-, or C-kinases. Results for the $100 \mathrm{kDa}$ and $65 \mathrm{kDa}$ organ of Corti phosphoproteins are plotted for cyclic nucleotide $(N=7$, each), CaM $(N=5)$ and lipid $(N=6)$ stimulation. Bars indicate standard errors of the means (SEM). Insets show results for statistically significant stimulations $(P<0.05$, paired $t$-test). The $65 \mathrm{kDa}$ protein appears to be an effective substrate for both C-kinase and CaM-kinase activity. Specificity of kinase-substrate relationships for other organ of Corti proteins is summarized in Table $\mathbf{I}$.
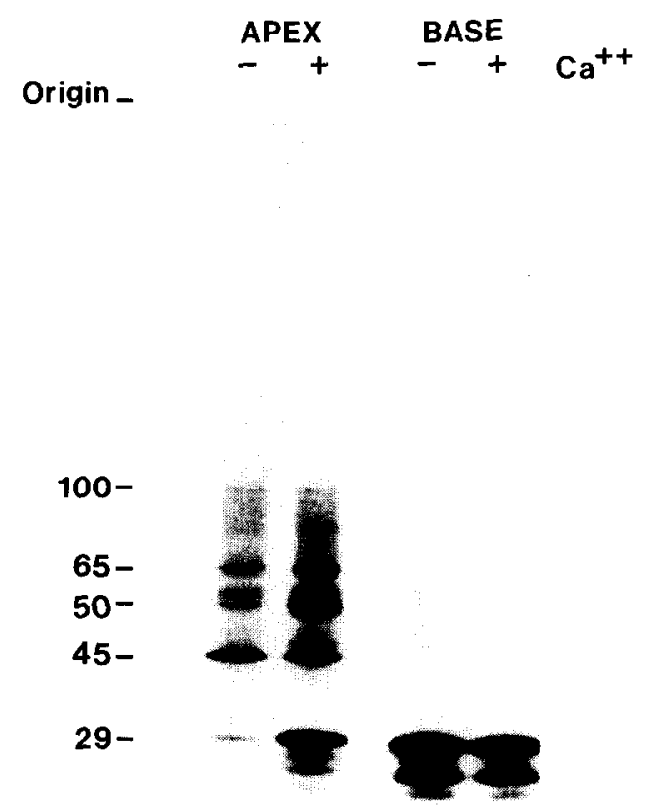

Fig. 4. Calcium-dependent protein phosphorylation in the organ of Corti varies between the base and apex. The organ of Corti was divided into two portions as described in the text. Tissue was labeled for $15 \mathrm{~min}$ in the absence $(0.2 \mathrm{mM}$ EGTA; -$)$ or presence $(0.2 \mathrm{mM}$ EGTA, $0.6 \mathrm{mM} \mathrm{CaCl}$; +) of calcium. Protcins were separated by SDS-PAGE and ${ }^{32} \mathrm{P}$-incorporation, shown in the figure, was detected by autoradiography. Base to apex differences in labeling are apparent for several proteins. Protein staining of the same gel showed no detectable differences in protein between base and apex and nearly identical amounts of total protein for each labeling condition (data not shown).

ration in apical tissue. Phosphorylation of the $47 \mathrm{kDa}$ protein also increased with calcium in apical tissue. In contrast, calcium did not affect phosphate incorporation in the $45 \mathrm{kDa}$ substrate.

In addition, the regional analysis of the organ of Corti revealed calcium-dependent increases in ${ }^{32} \mathrm{P}$-incorporation for four low molecular weight phosphoproteins $(23,25,27$ and $29 \mathrm{kDa})$ in apical tissue. This effect was apparently masked in assays of whole organ of Corti by calcium-independent phosphorylation of proteins of the same molecular weight in tissue from the base.

\section{Discussion}

Taking advantage of the sensitivity of radiolabeling techniques, we have provided the first evidence for the presence of three specific protein kinase activities in the organ of Corti and several of their potential protein substrates. Assays of spiral ganglion tissue additionally revealed the presence of two potentially novel proteins whose phosphorylation is blocked by calmod- 
ulin. We have also discovered an apparent differential regulation of calcium-dependent protein phosphorylation between the base and apex of the organ of Corti.

\section{Protein kinase activity}

The nervous system has a large capacity for integrating a variety of signals among cells. This is accomplished by voltage-dependent and ligand-gated ion channels and also by intracellular responses to specific combinations of second messengers. Second messenger systems are regulated through the action of a variety of extracellular 'first messenger' signals including transmitters, hormones and neuromodulatory substances. Target enzymes whose activity is, in turn, regulated by second messengers include protein kinases and phosphatases. Through amplifying cascade systems, these enzymes modulate processes which include ion channel conductance and synaptic events as well as the metabolic state and shape of cells. Additionally, a particular second messenger can participate in feedback networks, so called 'cross talk' pathways, to modulate responses to other second messengers.

Protein phosphorylation is one of the more widely studied mechanisms of second messenger action. Recent estimates suggest that as many as one third of a cell's proteins may undergo such a post-translational modification. This type of modulation typically follows a time course from seconds to much longer times as, for example, in the case of long term potentiation of synaptic efficacy (Malinow et al., 1988). Accordingly, we have reasoned that auditory responses that are candidates for regulation by protein phosphorylation will have relatively long time courses. These may include modulatory processes that regulate conductance states of ion channels or motility in outer hair cells, homeostatic processes involved in the regulation of blood flow, basilar membrane and stereocilia mechanical impedance, as well as metabolic and morphologic processes in development and damage repair.

Cyclic nucleotide dependent kinase activity. Two classes of protein kinases are stimulated by cyclic nucleotide second messengers. The cyclic AMP-dependent protein kinases are ubiquitous and have a broad range of protein substrates. The presence of cyclic AMP (Thalmann et al., 1979) and adenylate cyclase (Zajic et al. 1983) has been demonstrated in the organ of Corti. A role for this second messenger system, however, has not been established for that tissue. This report presents the first evidence for the presence of both the kinase and five putative substrates. Although the function of these proteins is as yet undetermined, their identification provides a new approach toward determining the role(s) of cyclic AMP in hearing.

Cyclic GMP-dependent protein kinases are much less evenly distributed in mammalian tissues. Perhaps as a consequence, few proteins have been identified as physiological substrates. The only known neuronal protein is G-substrate, an inhibitor of protein phosphatases 1 and $2 \mathrm{~A}$. Interestingly, the organ of Corti protein reported here as a potential substrate of cyclic GMP-dependent protein kinase and the cerebellar Gsubstrate are both $23 \mathrm{kDa}$ phosphoproteins. The importance of the cyclic GMP second messenger system in the inner ear is suggested by the presence of a gradient of cyclic GMP along the organ of Corti (Thalmann et al., 1979). These data suggest that phosphorylation of the $23 \mathrm{kDa}$ organ of Corti protein may be differentially regulated from base to apex. Further, they suggest a possible role for this protein. Although molecular weight comparison is far from sufficient to establish identity, it is still interesting to note that the molecular weight of the $23 \mathrm{kDa}$ phosphoprotein is very close to that reported for the well-characterized organ of Corti-specific protein OCP-II (Thalmann, 1990).

Protein kinase $C$ activity. Membrane lipids of the diacylglycerol family produced by phosphoinositide hydrolysis act as specific stimulators of the calcium-dependent protein kinase $C$ family (Nishizuka, 1989). Other membrane lipids, such as phosphatidylserine, have been found to be useful, in concert with diacylglycerols, to stimulate protein kinase $\mathrm{C}$ activity in tissue homogenates (Thomas et al., 1987). Thus, increased ${ }^{32} \mathrm{P}$-incorporation resulting from these agents is consistent with activity of protein kinase $\mathrm{C}$.

Phosphoinositide hydrolysis in the organ of Corti has recently been linked to muscarinic acetylcholine receptor activation (Guiramand et al., 1990; Niedzielski and Schacht, 1991). Presumably, this mechanism involves cholinergic efferent synapses (Altschuler et al., 1985), although this connection is, as yet, unconfirmed. The data provided here for lipid stimulation provide evidence for the presence of protein kinase $\mathrm{C}$ in the organ of Corti. It is, thus, possible that some of the proteins identified by lipid stimulation may be localized to hair cells and participate in the response of those cells to efferent nerve activity.

Calmodulin-dependent kinase activity. Calmodulindependent protein kinases have a widespread tissue distribution. They participate in diverse regulatory roles in synaptic release, protein synthesis, glycogen metabolism and contractility. Several distinct enzymes belong to this family including calcium/calmodulin-dependent protein kinase types I, II and III, phosphorylase kinase and myosin light chain kinase (for review, see Nairn et al., 1985).

In the experiments reported here for organ of Corti, calmodulin induced far greater increases in ${ }^{32} \mathrm{P}$-incorporation than did the cyclic nucleotides and lipids. This suggests that calmodulin-dependent kinases play major roles in the function of that tissue. This hypothesis is supported by the observation that stimulation of protein phosphorylation by calmodulin is relatively high in 
the organ of Corti compared to other tissues and comparable to that in brain (Fig. 1). It is further supported by the inhibitory effects of calmodulin antagonists on hair cell function (Corey et al., 1987; Dulon et al., 1990).

Differential regulation of protein phosphorylation between base and apex of the organ of Corti

Differential regulation between the base and apex of the organ of Corti has been detected for several proteins. These differences may correspond to functional, morphological and biochemical gradients which include mechanical impedance of the basilar membrane (von Bekesy, 1960), transmitter innervation (Altschuler et al., 1985; Fex et al. 1986), and transmittermediated phospholipid hydrolysis (Niedzielski and Schacht, 1991).

The results indicate the presence of a complex pattern of regulation in the organ of Corti and suggest some interesting predictions. 1) Differences in the phosphorylation of proteins with molecular weights between 45 and $100 \mathrm{kDa}$ may be due to different substrate distributions. This possibility, however, is not supported by any major differences in protein distribution detectable by SDS-PAGE suggesting that differences in distribution of kinase and phosphatase activities may be more likely. 2) Most of the proteins between 45 and $100 \mathrm{kDa}$ that were labeled in the apical tissue were identified in assays of whole tissue as potential calmodulin-dependent kinase substrates. Thus, presumably, the increased phosphate incorporation in response to calcium involves the action of endogenous calmodulin. 3) Not all of the putative calmodulin-dependent kinase substrates showed the same degree of stimulation by calcium. For example, the $45 \mathrm{kDa}$ phosphoprotein showed a very small response, if at all. This may be indicative of the presence of multiple types of calmodulin-dependent kinases in apical tissue. 4) The appearance of a $47 \mathrm{kDa}$ phosphoprotein in apical tissue that was not readily detected in assays of whole tissue suggests that the base of the organ of Corti may contain an inhibitor of a specific kinase acting on that protein. 5) Differences in patterns of phosphorylation of lower molecular weight proteins ( 23 to $29 \mathrm{kDa}$ ) suggest distinct differences in the regulation of the kinases acting on them.

\section{Conclusion}

The identification of several phosphoproteins regulated by four second messenger systems presented here provides the necessary insight for further experiments on the regulation of protein phosphorylation in the inner ear. A list of possible identities of some of the organ of Corti phosphoproteins is given in Table $\mathbf{I}$.
Many of the inner ear phosphoproteins are likely to be previously identified proteins of known function. Others may be either novel inner ear proteins or regulated by control pathways unique to the auditory system. Understanding this regulation and the interactions of these phosphoproteins will significantly enhance our knowledge of inner ear function and, perhaps, in some cases, lead to a better understanding of the function of these proteins in other less accessible and manipulable systems.

\section{Acknowledgements}

The authors wish to thank Rajiv Naik and Drs. Tetsufumi Ueda and Isolde Thalmann for their many thoughtful discussions during the planning and writing of this study. This work was supported by NIH program project grant DC-00078 and training grant DC00011.

\section{References}

Adelstein R.S. and Eisenberg E. (1980) Regulation and kinetics of the actin-myosin-ATP interaction. Ann. Rev. Biochem. 49, 921956.

Altschuler R.A., Kachar B., Rubio J.A., Parakkal M.H. and Fex J. (1985) Immunocytochemical localization of choline acetyltransferase-like immunoreactivity in the guinea pig cochlea. Brain Res. $338,1-11$.

Anniko M. and Schacht J. (1981) Phosphoinositides in the developing inner ear with references to brain, kidney and liver of the mouse. Int. J. Biochem. 13, 951-953.

Anniko M., Spangberg M.L. and Schacht J. (1981) Adenylate cyclase activity in the fetal and the early postnatal inner ear of the mouse. Hear. Res. 4, 11-22.

Bekesy, G. von (1960) Experiments in Hearing. McGraw-Hill, New York.

Berridge M.J. (1989) The Albert Lasker Medical Awards. Inositol trisphosphate, calcium, lithium, and cell signaling. J. Am. Med. Assoc. 262, 1834-1841.

Bretscher A. and Weber K. (1980) Fimbrin, a new microfilament-associated protein present in microvilli and other cell surface structures. J. Cell Biol. 86, 335-340.

Burgess W.H., Jemiolo D.K. and Kretsinger R.H. (1980) Interaction of calcium and calmodulin in the presence of sodium dodecyl sulfate. Biochim. Biophys. Acta 623, 257-270.

Campbell A.K. (1983) Intracellular Calcium, Its Universal Role as a Regulator. Wiley, New York.

Cohen P. (1989) The structure and regulation of protein phosphatases. Ann. Rev. Biochem. 58, 453-508.

Cohen P. and Klee C.B. (1988) Calmodulin. Elsevier, Amsterdam, The Netherlands.

Coling, D. and Schacht J. (1990) Protein phosphorylation in cochlear tissues. J. Cell Biol. 111, 421a.

Coling, D. and Schacht J. (1991) Calcium-dependent protein phosphorylation in the organ of Corti. Abstr. Assoc. Res. Otolaryngol. 14, 134.

Corey D.P., Smith W.J., Barres B.A. and Koroshetz W.J. (1987) Calmodulin inhibitors block adaptation in vestibular hair cells. Soc. Neurosci. Abstr. 13, 538. 
de Arruda M.V., Watson S., Lin C.S., Leavitt J. and Matsudaira P. (1990) Fimbrin is a homologue of the cytoplasmic phosphoprotein plastin and has domains homologous with calmodulin and actin gelation proteins. J. Cell Biol. 111, 1069-1079.

Dulon D., Zajic G. and Schacht J. (1990) Increasing intracellular free calcium induces circumferential contractions in isolated cochlear outer hair cells. J. Neurosci. 10, 1388-1397.

Fex J., Altschuler R.A., Kachar B., Wenthold R.J. and Zempel J.M (1986) GABA visualized by immunocytochemistry in the guinea pig cochlea in axons and endings of efferent neurons. Brain Res. $366,106-17$.

Flock $\AA$. (1980) Contractile proteins in hair cells. Hear. Res. 2, $411-412$.

Flock A., Cheung H.C., Flock B. and Utter G. (1981) Three sets of actin filaments in sensory cells of the inner ear. Identification and functional orientation determined by gel electrophoresis, immunofluorescence and electron microscopy. J. Neurocytol. 10, $133-147$.

Guiramand J., Mayat E., Bartolami S., Lenoir M., Rumigny J.F., Pujol R. and Recasens M. (1990) A M3 muscarinic receptor coupled to inositol phosphate formation in the rat cochlea? Biochem. Pharmacol. 39, 1913-1919.

Kilian P.L. and Schacht J. (1977) Phospholipid labeling in the noc tuid moth ear: A model for biochemical studies of transduction. In: M. Portmann, J.M. Aran (Eds.), Inner Ear Biology, Paris, INSERM, pp. 167-178.

Kilian P.L. and Schacht J. (1979) Polyphosphoinositides in insect muscle and sensory tissues. J. Neurochem. 32, 247-248.

Laemrnli U.K. (1970) Cleavage of structural proteins during the assembly of the head of bacteriophage T4. Nature 227, 680-685.

Levitan I.B., Chung S. and Reinhart P.H. (1990) Modulation of a single ion channel by several different protein kinases. Adv. Second Messenger Phosphoprotein Res. 24, 36-40.

Malinow R., Madison D.V. and Tsien R.W. (1988) Persistent protein kinase activity underlying long-term potentiation. Nature 335 , 820-824.

Nairn A.C., Hemmings H.C. and Greengard P. (1985) Protein kinases in the brain, Ann. Rev. Biochem. 54, 931-976.

Nairn A.C. and Palfrey H.C. (1987) Identification of the major $M_{r}$ 100,000 substrate calmodulin-dependent protein kinase $\mathrm{III}$ in mammalian cells as elongation factor- 2 . J. Biol. Chem. 262, $17299-17303$

Nestler E.J. and Greengard P. (1984) Protein phosphorylation in the nervous system. Wiley, New York.

Niedzielski A. and Schacht J. (1991) Phosphoinositide metabolism in the cochlea: Distribution of enzymes and carbachol-stimulated turnover. Abstr. Assuc. Res. Otolaryngol. 14, 135.

Nishizuka Y. (1989) The Albert Lasker Medical Awards. The family of protein kinase $\mathrm{C}$ for signal transduction. J. Am. Med. Assoc. $262,1826-1833$
Kyazenov A.G. (1987) $\mathrm{Ca}^{2+} /$ calmodulin-dependent phosphorylation of elongation factor 2. FEBS Lett. 214, 331-334.

Schacht J. (1982) Adenylate cyclase and cochlear fluid balance. Am. J. Otolaryngol. 3, 328-331.

Schacht J. (1985) Hormonal regulation of adenylate cyclase in the stria vascularis of the mouse. Hear. Res. 20, 9-13.

Schacht J. and Zenner H.P. (1987) Evidence that phosphoinositides mediate motility in cochlear outer hair cells. Hear. Res. 31, 155-159.

Schlichter D.J., Casnellie J.E. and Greengard P. (1978) An endogenous substrate for cGMP-dependent protein kinase in mammalian cerebellum. Nature 273, 61-62.

Shepherd G.M., Barres B.A. and Corey D.P. (1989) 'Bundle blot' purification and initial protein characterization of hair cell stereocilia. Proc. Natl. Acad. Sci. U.S.A. 86, 4973-4977.

Shpetner H.S. and Vallee R.B. (1989) Identification of dynamin, a novel mechanochemical enzyme that mediates interactions between microtubules. Cell 59, 421-432.

Slepecky N. and Chamberlain S.C. (1985) Immunoelectron microscopic and immunofluorescent localization of cytoskeletal and muscle-like contractile proteins in inner ear sensory hair cells Hear. Res. 20, 245-260.

Sutherland E.W. (1972) Studies on the mechanism of hormone action. Science 177, 401-408

Sziklai I., Kiss J.G. and Ribari O. (1986) Inhibition of myosin light-chain kinase activity in the organ of Corti by $0.3-5$ kilodalton substances of the otosclerotic perilymph. Arch. Otorhinolaryngol. 243, 229-232.

Thalmann R., Paloheimo S. and Thalmann I. (1979) Distribution of cyclic nucleotides in the organ of Corti. Acta Otolaryngol. 87, 375-380.

Thalmann I., Rosenthal H.L., Moore B.W. and Thalmann R. (1980) Organ of Corti-specific polypeptides: OCP-I and OCP-II. Arch. Otorhinolaryngol. 226, 123128.

Thalmann I., Takahashi K., Varghese J., Comegys T.H. and Thalmann R. (1990) Biochemical features of major organ of Corti proteins (OCP-I and OCP- II) including partial amino acid sequence. Laryngoscope 100, 99-105.

Thomas T.P., Gopalakrishna R. and Anderson W.B. (1987) Hormone-and tumor promoter-induced activation or membrane association of protein kinase $\mathrm{C}$ in intact cells. Methods Enzymol. 141, $399-411$.

Wang S. and Schacht J. (1990) Insulin stimulates protein synthesis and phospholipid signaling systems but does not regulate glucose uptake. Hear. Res. 47, 53-61.

Zajic G., Anniko M. and Schacht J. (1983) Cellular localization of adenylate cyclase in the developing and mature inner ear of the mouse. Hear. Res. 10, 249-261. 